\title{
The Nature of the Arab Uprising: An Analysis
}

\author{
Yahya Yechouti, PhD \\ Sidi Mohammed Ben Abdellah University, \\ Faculty of Letters \& Human sciences Sais, Fes, Morocco
}

Doi: 10.19044/esj.2017.v13n29p228 URL:http://dx.doi.org/10.19044/esj.2017.v13n29p228

\begin{abstract}
Many scholars have pondered over the equation of the MENA region (Middle East and North Africa) and its "exceptionality" without being able to reach a satisfactory answer to it: what makes this region so "resilient" to change, particularly given the rapid expansion of freedom elsewhere in the world. The Arab uprising of 2011 or what is known worldwide as the "Arab Spring" was deemed to be the harbinger of the end of the "curse/exceptionality," the curse of this seemingly permanent state of underdevelopment, corruption, and dictatorship. But then that Arab spring itself has turned out to be rather an Arab "winter," further vindicating the above prejudice, and pushing a lot of yesterday's enthusiastic crowds to be disappointed and to curse the day they thought about overthrowing their "beloved" dictators.

Drawing on other experiences elsewhere (mainly the spring of the European peoples in 1848 and the Fall of the Berlin Wall in 1989), this essay attempts humbly to participate in this debate and to offer, on the one hand, certain relativity both to the enthusiasm and disappointment that have accompanied respectively the Arab uprising. On the other hand, and besides reviewing the prolific literature that has been written about the possible causes of the upheaval, offers "tentative" notes that aim to participate in the general debate with no pretention of offering a comprehensive analysis to a movement whose ins and outs are still "blowing in the wind".
\end{abstract}

Keywords: Arab Spring, identity, Islam, NICT, culture, conspiracy theory

«Quand une fois la liberté a explosé dans une âme d'homme, les dieux ne peuvent plus rien contre cet homme-là » (Jean-Paul Sartre, Les Mouches)

"Uprisings have a body with which one can engage in combat. Revolutions, on the other hand, have a lot in common with ghosts."

(Metternich to Guizot, 31 October, 1847) 


\section{Introduction}

Different readings have been made of what is now known as the Arab Spring, chronologically a misnomer since the events in Tunisia and Egypt started in winter, and retrospectively an inappropriate label since the leading countries that experimented it turned all, with a slight exception of Tunisia, to be failing states and for the population worse economic conditions. The label was, nonetheless and understandably at the time, an optimistic metaphoric label in the tradition of other historic events that brought prosperity and peace to other regions in the world.

Before this major event, however, there have been numerous attempts at deciphering the MENA region's "resilience and exceptionality" to the winds of change and democracy, particularly given the rapid expansion of freedom elsewhere in the world. A lot of Orientalists and analysts related it to the nature of the Arab psyche and the religious framework in which it grew $^{59}$. Though some of these readings/analyses have solid arguments for support, a lot of them stem from an old time tradition of prejudice and stereotyping.

\section{Useful parallels}

Michael Zantovsky, in an article titled : "1989 and 2011: Compare and Contrast," written during the beginning of the Arab uprising, starts his essay by explaining the origins of the label given to the movement and argues that though it started in the winter of 2011, the "Arab Winter" as a label for the movement at that time would not do. He explains then that the Arab Spring:

borrowed from a European coinage, first employed as "the Spring of Nations" in reference to the revolutions and revolts

\footnotetext{
${ }^{59}$ A framework the orientalists and secularists think is reminiscent of the dominance of the Catholic church over the vastly illiterate European population during the middle ages, a population which managed to get back into "History" only when it managed to liberate itself from the shackles of servitude and ignorance imposed on it by this church. At that very moment, though, and in different intellectual Arab capitals in the Middle East (Damascus, Baghdad, Cairo, Fez,...) there were the first seeds of a booming intellectual movement. Indeed, the insightful debates Muslims had right after the death of the prophet over which should prevail: "the mind or the text/tradition," and which resulted in the formation of intellectual groups (such as al Ach'arit and the Muatazilit schools) attest to the healthy development of Muslim society and the flourishing of Arab thought and philosophy. Alas that development started to decline with the European Renaissance, vindicating the Khaldunian (Aderrahman Ibn Khaldun) theory of the wheel of civilization. A long sleep ensued for centuries... That Arab healthy debate came fortunately alive again during the Arab "nahda"/ renaissance at the end of the 19th and beginning of the 20th Century with major intellectual figures such as Rifa'a Rafi' El-Tahtawi, Jamal Eddine Al Afghani, Mohamed Abdou, and others.
} 
across Europe of 1848, which brought to many parts of the continent the ideas of independence, self-government, and participatory rule. The other well-known use is that of the Prague Spring of 1968, which meant a breath of fresh air from the long Communist winter. (Zantovsky, 2011, p. 14)

He then refutes the parallel that a lot of people hastened to draw between the events of 1989 - the fall of the Berlin Wall, which was never referred to as a spring, and brought down the whole totalitarian communist block - on the one hand, and the events of 2011 in the Arab world on the other hand, perhaps because, as he said, "then there was a complete seasonal change." (Zantovsky, 2011)

The French historian Alain Garrigou, in an article in Le monde diplomatique entitled "1948, le printemps des peuples," draws also an interesting parallel between what is going on in the Arab world and what happened in 1848 in Europe. He details how Europe's "spring" started with a "simple" incident at the gates of the French monarchy's palace in Paris, and how the French prime minister at the time ordered the royal guard to fire against the insurgents. This ended with the insurgents radicalizing their movement and ultimately propagating it to the rest of Europe. Some years later, and fearing the repercussions of the movement on their own existence, the European monarchies united in a counter-revolutionary movement that crashed the European "spring." 60

Likewise, and in an article entitled "The Arab Revolutions of 2011 Are more Like Europe in 1848 not 1989," Anne Applebaum argues that the Arab uprisings of 2011 are reminiscent of the European revolutions of 1848-complicated and messy. She drew parallels between what happened in Tunis, Cairo, Bengazi and what happened in Prague and Berlin two decades before. But like Michael Zantovsky above, she asserts that there is a major difference between the street revolutions that ended communism in Europe and the Arab uprising. The Eastern European revolt had a similar pattern because it followed in the wake of one single political event, the abrupt withdrawal of Soviet support for the local dictators. Whereas the Arab uprisings were the product of multiple changes: economic, technological, and demographic. In that sense, they have a lot more in common with 1848 than with 1989.

Applebaum concludes that though inspired very generally by the ideas of liberal nationalism and democracy, the mostly middle-class demonstrators of 1848 had, like their Arab counterparts, very different goals in different countries. For example, in Hungary they demanded

${ }^{60}$ This reminds us of what happened in 2011 when a lot of Gulf monarchies (Bahrein, UAE, Saoudi Arabia, Qatar, Kuwait, and Sultanate of Oman) united against the insurgents in their respective countries and in the region as a whole. 
independence from Hapsburg Austria. In what is now Germany, they aimed to unify the German-speaking people into a single state. In France, they wanted to overthrow the monarchy. (Applebaum, 2011)

\section{Roots and causes}

As for the causes of the Arab uprising, a lot has already been said and many political analysts divide the causes of the Arab spring into two categories: the long term root causes leading to the uprisings, and other "spontaneous and direct factors" which triggered the sudden, on the spot organization of protest:

Long-term, embedded structural factors leading to the Arab Spring comprise corruption, State repression, denial of political freedoms, the failure of the traditional powers to accommodate and recognize new youth movements, the development of gaps between the various regions inside one country, the domination of economic resources by the few through the alliance of State authority and the capital of powerful private individuals, and the spread of poverty and unemployment among massive swathes of the population.... On the other hand, the spontaneous factors which acted as catalysts sparking the uprisings on the spot were Mohammed Bouazizi's selfimmolation in Tunisia, the torture of Khaled Said in Egypt, and the arrest of the political activist, Fathi Terbel in Libya. According to current consensus among political analysts, the mix of the long term structural factors listed above set ablaze by the spontaneous sparks arising in Tunisia, Egypt, and Libya to create the waves of outrage which fueled the Arab uprisings. (Osman Saleh, 2013, p. 188)

The author of the quote above, Kamal Eldin Osman Saleh, then went on to denounce the oversimplification of certain western intellectuals, among whom the famous New York Times columnist Thomas Friedman who, in an article entitled "It Is Just the Beginning" argued intriguingly that the election of the first black president of the United States, Barack Obama, and the resignation of the former Israeli prime minister, Ehud Olmert, on allegations of corruption, are also among the major factors that led to the popular uprisings in the Arab world. (Osman Saleh, 2013) ${ }^{61}$

\footnotetext{
${ }^{61}$ Sometimes, the purpose behind these "original" analyses, according to the author, is to
} 
Other analysts and observers offered the NICTs (New Information and Communication Technologies) as the major instigator and mobilizer for the Arab revolt, calling it in the process: revolution 2.0 or Facebook revolution. Though there is no denial that technology did help in the ignition of and the mobilization for this leaderless movement, some observers, on the one hand, put into question the extent of this involvement, denying the Arab youth the privilege to be the first generation in the world to use massively the digital technology as a major means of "revolution." Others like the EgyptoSuiss intellectual Tarek Ramadan, on the other hand, saw in people like the famous young Egyptian computer expert and activitst, Wael Ghonim, and the like, a kind of "Troyan horse" of Western powers...(Ramadan, 2012) ${ }^{62}$

Olivier Roy in an essay in Le Monde newspaper titled "Révolution Post-islamiste," distinguishes clearly between the Arab generations of the 70 s and 80 s on the one hand, and their children who led the revolt in 2011, on the other. He cites the example of the Muslim brothers in Egypt who had a huge influence on the population and which had pushed the Egyptian president Husni Mubarak to compose with them. (Roy, 2011). We all remember also the impact the FIS (Front Islamique du Salut) had in Algeria on the population and how they managed to legally and rightfully won the legislative elections in 1991, which the military cadres denied them, leading the country into civil war.

The generation of the Arab uprising, according to O. Roy, is "postIslamist," still conservative indeed (more mosques, more women wearing the veil, and more Islamic signs), but a generation that understands, according to him, that religion can be practiced privately. (Roy, 2011) In other words, political Islam and its ideal to transform radically Muslim societies "à l'iranienne" was abandoned by the younger Arab generation in favor of more urgent needs of democracy, justice, a fair share of wealth, and mainly less corruption, a position shared by many pundits:

In a radical departure from previous political generations, which were either nationalist or Islamist, the current protestors are thus seen as the standard-bearers of a cultural and intellectual revolution. These new men and women have allegedly forged "a new relationship to the self, a new relationship with others, with the world and in particular with

deprive the Arabs of their capacity to be masters of their own destiny, which implies that they are always in need of external "models" to be inspired...

${ }^{62}$ The author does not go as far as considering this as part of a conspiracy to tumble Arab regimes, since he admits that these young people were simple activists trained by Western powers. He does state, however, that the United States long before the start of the Arab upheavals had recruited and trained groups of Arab youth with the aim to implement "peaceful protest" within their respective countries. 
the West", as well as with political, religious and familial authorities. (Bennani-Chraibi, Fillieule and Raillard, 2012, p. 10)

\section{Arab vs Amazigh, Modern vs Traditional:}

So far, I have been discussing the issue of the "Arab spring" without tackling the complex problem related to the epithet/component "Arab" in it. This is a quite thorny question because a lot of people do not find themselves into the label "Arab spring/uprising/revolt," and continue to think that as long as this issue of identity has not been resolved for this large part of the Maghrebi population, we cannot speak of any settlement or appeased outlook to the future. Every now and then, Amazigh dissidents organise huge protests as a reminder that six years after the first uprisings, nothing has been settled yet.

A lot of Amazigh and other "minorities"63 in the Arab world rightfully put the question: What made the world define the phenomenon that took place in this region as "Arab?" Is it a question of concomitant borders, but borders, as we all know, are artificial and were most of the time imposed by the former colonising western powers? There are nations without borders and borders without coherent nations. ${ }^{64}$ Or was the name due to the fact that a majority of the inhabitants of this region speak Arabic?

This polarisation does not end there. It goes, as demonstrated before, to questions of generation gap, modernity vs tradition or authenticity, extreme poverty vs extreme wealth, or nationalist vs Islamist. Morocco offers the archetypical illustration of these polarities. The bright side of the Arab uprising in this country was illustrated by the famous youth movement called "20 Fevrier." The militants belonged to different factions that were in utter opposition to each other when it comes to their ideologies/identities, we had ultra-Marxist-Leninist groups as well as ultra-religious ones, all walking together in public marches and demonstrations, claiming a refusal of tyranny and injustice, but conspicuously contradictory about the ultimate society they aim to achieve.

This polarisation is reflected even in the intellectual circles that try to defend respectively the "chapel"/group they represent. Here is for example an interesting interview with Tariq Ramadan and Abdelwahab Meddeb in Le Monde newspaper entitled "De la charia à l'islamophobie, de l'homosexualité au statut de la femme", held in April 2011, and how each one of these two Arab intellectuals holds quite opposing positions as to what

${ }^{63}$ I put "minority" between inverted commas because the Amazigh in Morocco constitute a "majority."

${ }^{64}$ We think here of the Kurds, the Native Americans, the Amazigh, the former states of the USSR or of Yugoslavia. 
defines the identities of the youngsters who protested in the "Arab Spring." While Ramadan acknowledges that the movement is certainly not Islamist, he condemns those who claim it to be anti-Islamic. On the other hand, A. Meddeb openly, like Olivier Roy before, rejects any religious dimension of the movement and defines it rather as a humanist movement. He maintains that it is not post-Islamic but beyond Islam.

Notwithstanding these polarisations, observers note that if contained, they could simply be part of the normal course of any movement born in undemocratic environments with a predominance of the leader's unique opinion and voice. That is why some analysts consider that in spite of these shortcomings, the movement is the Arab world's exit into history, "an exit from a sterile closed place into a land of painful and consequential choices," a shift from the status of subjects to the status of citizens.(Keane, 2011) ${ }^{65}$

Nobody knows what would happen next; this is the trademark of revolutions: "they unchain struggles for freedom and power manoeuvres that inject great uncertainty into the world." (Keane, 2011) And as such, we should expect more "ups and downs," but we should especially be very patient and extremely careful with hasty judgements or actions that could make things far worse.

Tarek Ramadan insists that:

"analysis in the heat of the action is never easy, especially as events unfold and their causes-and the future itself-remain clouded with uncertainty. .. As vital as it appears to give the Arab uprisings a name, we should be cautious about rushing to define them. Not knowing exactly what the components of these nonviolent, transnational mass movements are, we know even less about their eventual outcome.(Ramadan, 2012, p. 1)

\section{Satellite reception, Al Jazeera Channel, and the theory of conspiracy:}

Besides the objective and spontaneous reasons and causes of the Arab uprising mentioned above, there are other reasons that should be mentioned, among which the role of satellite reception in general and the reception by the end of the 1990s of the Qatari Aljazeera TV channel, in particular.

Al Jazeera helped to mold "a new Arab public", "to circumvent official demands and to promote unprecedented media pluralism granting space" to multiple opinions (ar-ra'y wa ar-ra'y al-akhar) (Bennani-Chraïbi,

\footnotetext{
${ }^{65}$ This could be corroborated through the example of Israel, a very young state made of ultra-religious and ultra-liberal groups of different, and often very distant origins, but which still form one of the rare "democratic" countries in the region, at least from the perspective of the Western countries; since we Arab-Muslims consider it rather a racist and segregationist state in its dealing with the Arab-Israeli citizens.
} 
Fillieule and Raillard, 2012). ${ }^{66}$ I remember how we were mesmerized by the debate of the "al Ittijah Al mo'akiss (the opposite direction) program. The style of the debate was definitely new to the Arab world, especially for those who were not familiar with Western TV channels. We felt that it is high time for the Arab individual to triumph over sectarianism, or tribal allegiances. We felt for the first time that this Arab program was talking to us, evoking topics kept taboo for decades, with two guests who spoke their minds, and a TV anchor who heated the debate by provoking his guests into fiercer arguments.

As the late Fatima Mernissi remarked in an interview in 2006, The satellite channels have strengthened a pan-Arab space of reception that has become a unique transnational market. The old information networks characterized by a propaganda function have been replaced by others, with new professional guide-lines conforming to the international standards. In addition to the spreading of satellite dishes which tower even on the balconies of Casablanca over the shanty town. (Mernissi, 2006)

Mernissi also refers to the role of cyber cafes which started in the 80's and how they increased in number and represented the "new frontier" of communication in the Arab world. The enthusiasm manifested by Fatima Mernissi towards the spread of Internet and satellite televisions as means of democratization and expression was a precursor to the uprising that was going to take place a few years later. (Mernissi, 2006)

As for those orientalists or others who still find us "exceptional", and though I am not a fervent supporter of the conspiracy theory, I have reasons to think, based on factual arguments, that the Arab movement was not completely spontaneous. The objective and circumstantial causes mentioned before remain facts that no one can deny, but as Tarek Ramadan states in his book, Islam and the Arab Awakening:

The uprisings that swept the Arab world did not come from nowhere. As early as 2003, there had been talk of democratization in the MENA zone. It had, in fact, become then-president George W. Bush's key argument for

${ }^{66}$ From outside, Al Jazeera had all the aspects of a professional and unbiased TV channel, but after investigations carried by other media who felt dwarfed by this new comer, revelations started to "pour in" and revealed that this channel is part of an American Israeli scheme to create the famous «creative chaos » in the Arab world. Though there is a lot of truth to this, it remains that this channel "reshaped" rather positively the Arab mind, at least until a certain period of time, before Qatar started blatantly to use the channel as a propaganda medium to implement its political agenda. In all cases, if the channel were conceived as a mere propaganda tool for any party, it turned out into a Frankenstein that escaped the leash... 
intervention in Iraq. One year later, young MENA cyberdissidents were signing up for training courses in nonviolent protest. Institutions funded by the American administration and/or major private firms organized lectures and seminars and set up networks that would provide training for young leaders who were given instruction in the use of the Internet and social networks... These are facts that just won't $\square$ away; they must be studied and put in context if we wish to gain a better understanding of the dynamics and issues involved. (Ramadan, 2012, p. 2)

Once again, I am not obsessed with the idea that everything is not what it appears to be, that "ghosts" are everywhere looking over our shoulders and playing tricks on us. In other words, we should not conclude that the whole upheaval was a manipulation of the West or foreign forces because, in this case, we will prove further that we are weak and not masters of our own will and destiny, and we will end up being puppets in the hands of those "dark forces."

At the same time, we should be very careful with the schemes/plots of our adversaries/enemies. This is quite fair! Each one is defending its territory; it $\mathrm{i} \square$ a que $₫ \mathrm{ti} \square \mathrm{n} \square \mathrm{f} \square \mathrm{d}\lceil$ en $\sqsubset$ e. $t \mathrm{w} \square$ uld be naïve $\mathrm{f} \square \mathrm{r} u \mathrm{u} \square$ think that Israel for example is not doing everything in its power to "hack" our governments, economies... so as to carry preemptive attacks. It has done so ruthlessly since its foundation in $1948 \ldots{ }^{67}$ What we should do first is to look for the enemy within, that sixth battalion that keeps stabbing us in the back only to discover, through WikiLeaks for example, that it is nobody else but your country's leader, your next door neighbor, or worse of it all, your own brother or sister... ${ }^{68}$

\section{Conclusion}

It is never easy to draw conclusions about a movement still in its nascent phase, nor is it safe to state that these or those are the causes of an uprising or revolt taking place somewhere. The combination of very complex circumstances and "luck" are always there to explain why a rebellion turned into a revolt and did not go further, while another "insignificant" event turned into a full-fledged revolution or a major historic event. It is nonetheless always easier to delve into a lengthy explanation and analysis

\footnotetext{
${ }^{67}$ The only aspect not so "natural" about it is the double standards the Western world holds, mainly the US, when it comes to condemn its thug-like assassinations and infiltrations into the territories of sovereign states.

${ }^{68}$ I do believe that, among all the threats facing the Arab-Muslim world, this "enemy within" is definitely the worst... I intend to develop this idea in my future writings, and hope it will become an axis of research for Arab-Muslim intelligentsia.
} 
once an uprising starts. This is probably why it is extremely rare to find pundits who could have predicted the fall of the communist bloc, the $9 / 11$ attacks, or the Arab uprising.

We should also be wary of overly generalizing interpretations that seek to describe the upheavals of 2011 as the product of a unified wave of insurrections. Aside from the domino effect caused by the fall of the Tunisian dictator, Z. Ben Ali, the trajectory and the shape taken by the different Arab uprisings are all very different. Each country has developed and learned differently, too. The Algerian people for example learned the lesson earlier, and have preferred to be under the throes of a military junta that is upholding a very sick president that "reigns but not rules" rather than re-experiment the terrible years of the 1990s. Thus, and apart from the "Kabils" in the north, and the Touaregs in the South, few in Algeria have been enthusiastic all along these years of protests about taking part in them, refraining from emulating other people in other Arab neighbouring countries. They still had in mind "the dirty war/la sale guerre" when Algeria went through the bloodiest civil war the country had ever known. ${ }^{69}$

The time has come for each one of us to take his/her responsibility, to stop looking for scapegoats and blaming the West for our failures. I can say, however, that there are two major beneficiaries of what has become now "the Arab Winter." The first is certainly the State of Israel which, with a "minimum" effort and manipulation, has managed to marginalize quite dramatically the Palestinian cause and the pan-Arabism movement, enjoying the show, like Nero with Rome, of an Arab world set ablaze, and making the dream of the Arab-Muslim unity a far-fetched dream. This is the dark side of the movement; the bright side is certainly the new Arab citizen who seems to have overcome definitely the fear factor and does no more hesitate to stand for his/her rights.

One final positive note to end this essay: Tarek Ramadan's recommendation in his book Islam and the Arab Awakening:

Arab and Muslim majority societies must jettison their historic posture as victims and reconcile themselves with the course of history that millions of women and men accelerated so massively by coming out into the streets. Their responsibility is a historic one: they must entertain no illusions about what is at stake, be wary of attempts at manipulation, and be determined to carry out essential reforms with the full participation of all citizens, women and men, from all social classes and religious and cultural backgrounds. (Ramadan, 2012, p. 3)

${ }^{69}$ For further information about the Algerian civil war, see:
https://en.wikipedia.org/wiki/Algerian_Civil_War




\section{Referencss:}

1. Ali, Tarek, (2003). The Clash of Fundamentalisms, London, New York : Verso.

2. «Arrêt sur Manif” » (a photo-report), Telquel magazine (Morocco), 9 au 15 avril, 2011.

3. Castells, Manuel, (2010). The power of Identity: the Information Age : Economy, Society, and Culture, Blackwell Publishing Ltd.

4. Coleman, Simon ; Collins, Peter Jeffrey, ((2004). Religion, Identity and Change: Perspectives on Global Transformations, Ashgate publishing Limited.

5. El Alaoui, Hicham Ben Abdallah, (2010). «Les intellectuels arabes entre Etats et intégrisme, » Le monde diplomatique, aout. 2010.

6. Garrigou, Alain, 1848, (2011). le printemps des peuples Le monde diplomatique, mai 2011.

7. Gresh, Alain, (2011). «Les chemins de la liberté, » Manière de voir » \#117, juin-juillet 2011.

8. Islam Encountering Globalisation, (2002). Edited by Ali Mohammadi, London: Routledge.

9. Mitropolitski, Simeon, (2003). "Arab Countries: Beyond the Stereotypes," 12 December 2003 C IRED.Com, Inc.

10. Ramadan, Tarek, (2012). Islam and the Arab Awakening, New York : Oxford University Press , 2012.

11. Taylor, Maghaddam, Wright, (2003). Social Psychology in Crosscultural Perspective, NewYork: Freeman.

12. Todorov, Tzvetan, (2010). The Fear of Barbarians: Beyond the Clash of Civilisations, University of Chicago Press.

\section{Online references:}

13. Abbas, Fatin , "Year of the Boomerang? Frantz Fanon and the Arab Uprisings," $11 \quad$ April 2011. http://www.opendemocracy.net/5050/fatin-abbas/year-of-boomerangfrantz-fanon-and-arab-uprisings

14. Adib-Moghaddam, Arshin "Postmodern Islam and the Arab Revolts" 7 March, 2011. (www.opendemocracy.net)

15. Akel, Bassil, "Stereotypes and Misconceptions: Islam and the Western Media," http://muslimvillage.com/2002/07/20/534/534stereotypes-and-misconceptions-islam-and-the-western-media/

16. Ali, Syed Hamad, "The hidden agenda in stereotyping Muslims," http:/gulfnews.com/news/world/uk/the-hidden-agenda-instereotyping-muslims-1.632087

17. Applebaum, Anne, "The Arab Revolutions of 2011 are more like Europe in 1848, not 1989," Slate, February 21, 2011, 
http://www.slate.com/articles/news_and_politics/foreigners/2011/02/ every_revolution_is_.... (in collaborating with Jstor.)

18. « De la charia à l'islamophobie, de l'homosexualité au statut de la femme, » interview avec Tariq Ramadan et Abdelwahab Meddeb, » http://www.lemonde.fr/idees/article/2011/04/22/de-la-charia-a-lislamophobie-de-l-homosexualite-au-statut-de-lafemme_1511640_3232.html

19. Keane, John "Refolution in the Arab World," 28 April 2011. (www.opendemocracy.net)

20. New Arab Mass-Media Vehicles of Democracy? Interview with Fatima Mernissi, Francesco Alfonso Leccese in Oriente Moderno, Nuova serie, Anno 25 (86), Nr. 2 (2006), pp. 345-356 Published by: Istituto per l'Oriente C. A. Nallino (URL: http://www.jstor.org/stable/25818068)

21. Osman Salih, Kamal Eldin, "The Roots and Causes of the 2011 Arab Uprisings." in Arab Studies Quarterly, Vol. 35, No. 2 (Spring 2013), pp. 184-206 Published by: Pluto Journals. (in collaborating with Jstor.)

22. "Towards a sociology of revolutionary situations: Reflections on the Arab uprisings" by Mounia Bennani-Chraïbi, Olivier Fillieule and Sarah-Louise Raillard in: Revue française de science politique (English Edition), Vol. 62, No. 5-6, Arab Uprisings, Reflections on Revolutionary Situations in Context (2012), pp. 1-29 Published by: Sciences Po University Press (http://www.jstor.org/stable/revfranscipoleng.62.5-6.1)

23. Zajda, Joseph I. "Living Together: Globalisation, Education and Intercultural Dialogue,"

24. http://www.uws.edu.au/equity_diversity/equity_and_diversity/tools_a nd_resources/conference_documents/living_together_globalisation,_ education_and_intercultural_dialogue

25. Zantovsky, Michael, "1989 and 2011: Compare and Contrast." World Affairs, Vol. 174, No. 2 (July/August 2011), pp. 13-24. (Sage Publications, Inc. http://www.jstor.org/stable/41290329) 